\title{
A concept of a turbocharger test stand
}

\begin{abstract}
The paper presents selected possibilities of vehicle turbocharger testing using an exhaust gas generator (based on a passenger vehicle) designed in the laboratory on the engine test bed. An outline of the range of turbocharger testing, the design and main characteristics of the test stand have been described. Several validation tests have been presented in terms of the technical parameters, operativeness, and functionality. Basic parameters of the engine have been analyzed that have impact on the turbocharger speed.
\end{abstract}

Key words: turbocharger, engine operation, test stand

\section{Koncepcja stanowiska do badania turbosprężarek silników spalinowych}

\begin{abstract}
W artykule przedstawiono wybrane możliwości badania turbosprężarek układu doładowania samochodowego silnika spalinowego z wykorzystaniem wytwornicy spalin opartej na silniku spalinowym samochodu osobowego, zbudowanej na hamowni silnikowej laboratorium. Omówiono w zarysie zakres badań turbosprężarek, zaprezentowano budowę stanowiska oraz przedstawiono jego główne cechy charakterystyczne. Przedstawiono kilka testów sprawdzających możliwości techniczne, przydatność oraz poprawność funkcjonowania układu zasilnia turbosprężarki. Dokonano analizy podstawowych parametrów silnika mających bezpośredni wpływ na prędkości obrotowe wału turbosprężarki.
\end{abstract}

Słowa kluczowe: turbosprężarka, eksploatacja, stanowisko badawcze

\section{Introduction}

Turbocharging of a combustion engines is one of the most popular method to improve the engine operating indexes. It influences the overall engine efficiency, increases the volumetric and mass power coefficient (downsizing), reduces unit exhaust emissions etc. For this reason research is conducted on design, production, operation, and recycling stages of these devices. Much attention is also devoted to the cooperation of the turbocharger with the engine, the principle of power control and cooperation between various Turbocharging subsystems.

The theoretical and experimental analyses are carried out by automotive research and development centers (car makers) and university centers.

Based on earlier publications, the paper presents the results of simulations and experiments from the discussed topic, narrowing the cognitive interest to a selected turbocharger. The information presented in the publications was obtained during research on small and medium engines (used in vehicles and locomotives).

For turbocharger research, proper test stands are designed and constructed. They should meet the basic research requirements i.e.: to accelerate the turbocharger rotor to a predetermined speed (for given conditions), feed lubricant to provide bearing lubrication, record physical parameters (temperature, pressure, vibrations), control the actuators etc. The paper presents the technical possibilities of a selected, existing test stand and the scope of works performed with its use.

\section{Wstęp}

Turbodoładowanie silnika spalinowego jest jednym z najbardziej rozpowszechnionych sposobów poprawy wskaźników pracy silnika przez wpływanie na: poprawę sprawności ogólnej silnika, zwiększenie objętościowego i masowego współczynnika mocy (downsizing), zmniejszenie jednostkowej emisji toksycznych składników splin itd. $\mathrm{Z}$ tego powodu prowadzi się badania $\mathrm{m}$.in. $\mathrm{z}$ zakresu konstrukcji, produkcji, eksploatacji, recyklingu tych urządzeń. Wiele uwagi poświęca się także współpracy silnika z turbosprężarką, sposobowi regulacji mocy, współpracy między różnymi systemami doładowania.

Analizę teoretyczną i eksperymentalną prowadzą zarówno ośrodki badawczo-rozwojowe należące do firm bądź konsorcjów zajmujących się produkcją, jak i instytuty uczelniane.

W artykule, opierając się na publikacjach, przedstawiono wyniki symulacji i eksperymentów z omawianego zakresu, zawężając zainteresowanie poznawcze do wybranego elementu systemu doładowania, jakim jest turbosprężarka. Przedstawione w publikacjach informacje uzyskano podczas badań nad silnikami spalinowymi małej i średniej mocy (stosowanymi w m.in. pojazdach samochodowych, lokomotywach).

Do badań prowadzonych nad turbosprężarkami konstruuje się odpowiednie stanowiska. Powinny one spełniać podstawowe wymagania badawcze, tj.: rozpędzić wirnik turbosprężarki do określonej (zadanej w określonych warunkach) prędkości obrotowej, dostarczyć olej do smarowania łożysk, rejestrować odpowiednie parametry fizyczne (temperatura, 


\section{Scope of applicability of turbocharger tests stands}

\subsection{Creation of flow characteristics}

The characteristics are created by measuring the quotient of the static pressures downstream of the turbine or compressor vanes and determining the mass flow through the vanes at given rotor speeds. It is noteworthy that, due to the mechanical connection between the rotors of both machines, the characteristics of the compressor heavily depend on the characteristics of the turbine. Example characteristics have been shown in Fig. 1.

a)

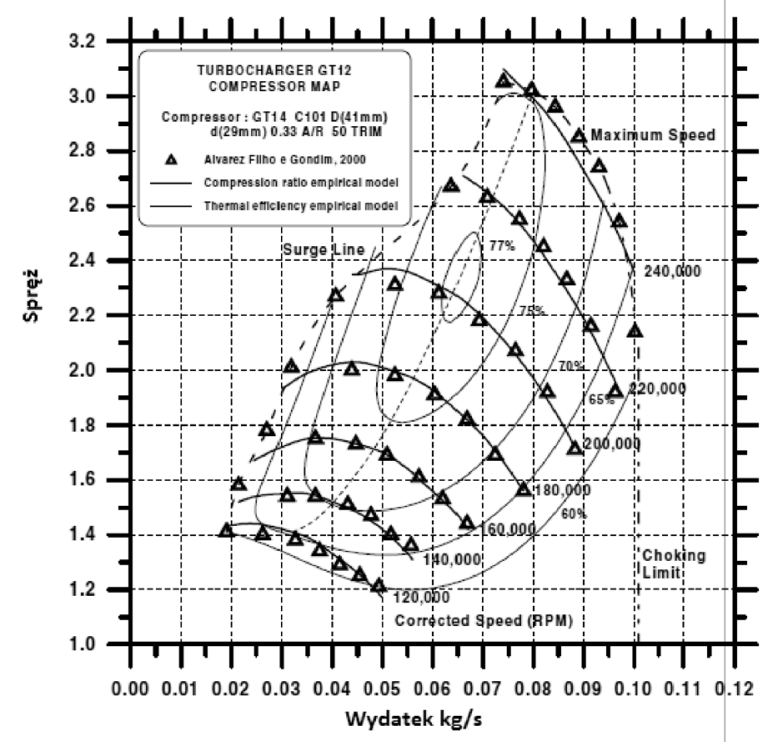

ciśnienie, drgania), wpływać na układy regulacyjne itp. W artykule przedstawiono możliwości techniczne wybranego, istniejącego stanowiska badawczego oraz zakres prac wykonywanych przy jego użyciu.

\section{Zakres przydatności stanowisk do badań turbosprężarek}

\subsection{Tworzenie charakterystyk przepływowych}

Charakterystyki sporządza się przez pomiar ilorazu ciśnień statycznych przed i za łopatkami turbiny czy sprężarki oraz wyznaczenie strumienia masy czynnika przepływającego przez łopatki przy zadanych prędkościach obrotowych.

b)

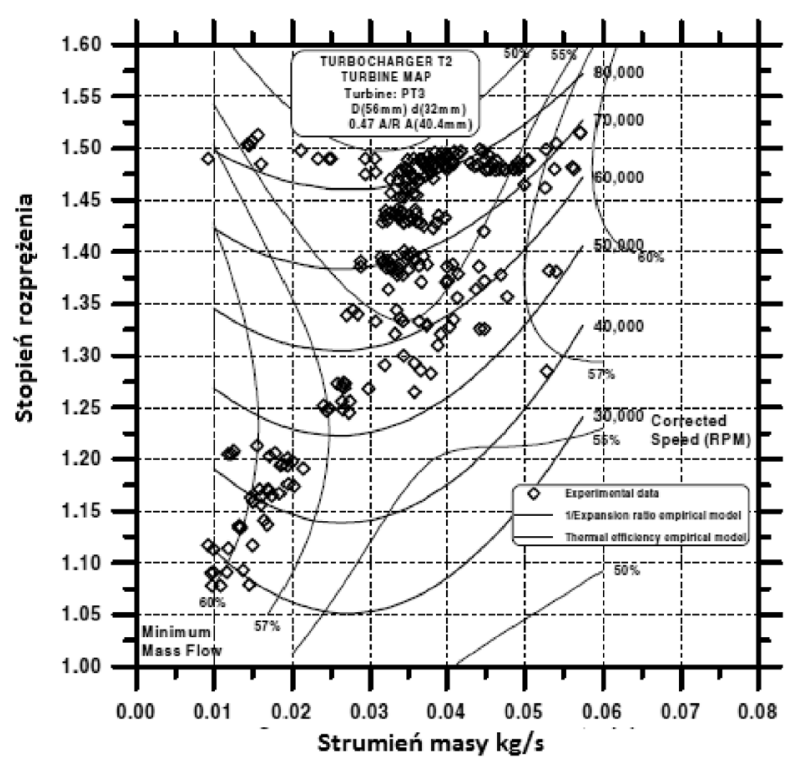

Fig. 1. Flow characteristics: a) compressor, b) turbine

Rys. 1. Charakterystyki przeptywowe: a) sprężarki, b) turbiny

The characteristics of a turbocharger are most often performed in the last stage of the design process when it is vital to validate the selection of the geometrical proportions of the components such as rotors or turbocharger shrouds. Their determination also provides the operating boundaries of the turbine or the compressor. For a turbine, the most important limit is the limit related to the strength of its components and the boundary of the minimum isentropic efficiency of decompression - the choke boundary. Similar extreme parameters are determined in relation to compressor taking into account the pumpage boundaries, resulting from the impossibility to compress insufficient medium flows. The performed characteristics are correlated with appropriate parameters of the engine. The 'suction curves (showing the engine air demand) are determined in the first place.

\subsection{Research of turbocharger lubrication and bearings}

Because of the cooperation of the turbocharger system with the engine in the times of exhaust emissions getting very stringent, a very important parameter is the amount
Znamienne jest jednak to, że charakterystyka sprężarki ściśle zależy od charakterystyki turbiny, ze względu na mechaniczną łączność pomiędzy wirnikami obu maszyn. Przykładowo sporządzone charakterystyki przedstawiono na rys. 1 .

Charakterystyk turbosprężarek wykorzystuje się najczęściej w ostatnim ogniwie procesu projektowania tych urządzeń, gdzie istotne jest sprawdzenie doboru geometrycznych proporcji elementów składowych, takich jak wirniki czy korpusy. Ich sporządzenie daje również możliwości określenia granic działania turbiny czy sprężarki. Dla turbiny określa się limit związany przede wszystkim z wytrzymałością elementów oraz granicę minimalnej sprawności izentropowej rozprężania, tzw. granicę zdławienia. Podobne parametry ekstremalne określa się w odniesieniu do sprężarek, z uwzględnieniem także tzw. granicy pompażu, wynikającej z niemożliwości sprężania zbyt małych strumieni masy czynnika. Sporządzone charakterystyki koreluje się z odpowiednio określonymi parametrami pracy silnika spalinowego. Określa się przede wszystkim tzw. linie zasysania silnika, ilustrujące zapotrzebowanie silnika na powietrze. 
of consumed oil during turbocharger operation. The investigations can be conducted in two ways. The first method incorporates the use of oil separator installed downstream of the compressor. The tests are conducted in relation to the engine speed and load. Example results described in [1] including a diagram have been shown in Fig. 2. Analyzing the figure, we may observe that the amount of oil passing trough the turbocharger bearings heavily depends on the engine load.

a)

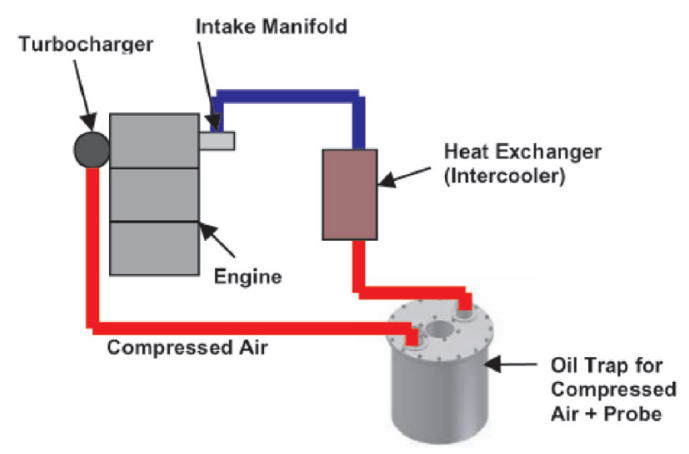

\subsection{Badania w obrębie układu smarowania i łożysko- wania turbosprężarki}

Ze względu na współpracę układu turbosprężarki z silnikiem spalinowym, w dobie zaostrzonych norm toksyczności spalin, bardzo istotnym parametrem jest ilość zużywanego oleju podczas pracy turbosprężarki. Badania można prowadzić dwoma sposobami. W pierwszym, stosując separator oleju zainstalowany za sprężarką, badań dokonuje się w zależności od obciążenia i prędkości obrotowej silnika.

Fig. 2. Turbocharger oil consumption measured on the compressor side: a) test stand diagram, b) example results Rys. 2. Pomiar zużycia oleju przez turbosprężarkę mierzony po stronie sprężarki: a) schemat stanowiska, b) przyktadowe wyniki

The other method is the measurement of the oil flow by the gravimetric method. This method requires a standalone lubrication system fitted with a scale measuring the mass of the oil accumulating in the tank. The methodology of this type of measurement has been presented, inter alia, in [2] containing the results obtained by Agip Petrol. The diagram of the turbocharger oil consumption test stand along with the results for mineral and synthetic oil have been shown in Fig. 3. From the tests it results that the consumption of oil by the turbocharger under given conditions is lower by $25 \%$ if synthetic oil is used.

a)

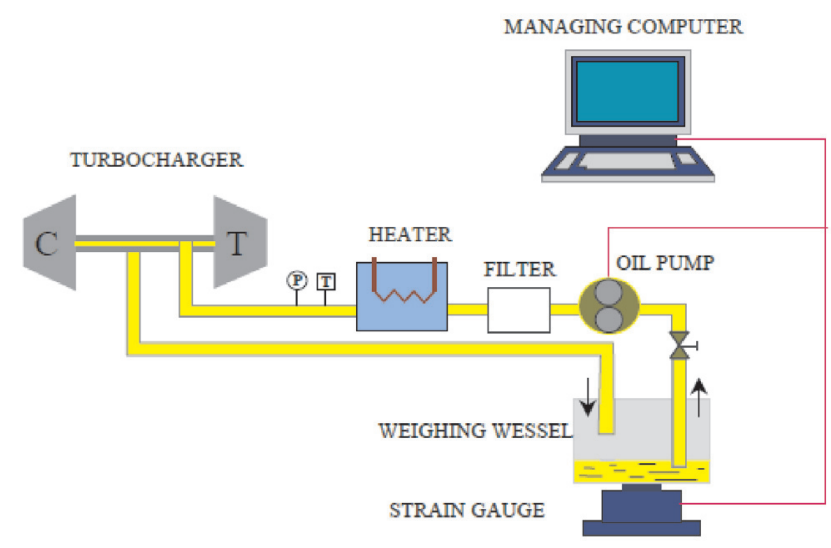

Przykładowe wyniki badań opisane w pracy [1] wraz ze schematem ideowym przedstawiono na rys. 2. Analizując rysunek, można zaobserwować, że ilość oleju przedostającego się przez łożyska turbosprężarki po stronie sprężarki silnie zależy od obciążenia silnika.

Drugi sposób badań to mierzenie strumienia zużycia oleju metodą wagową. Metoda wymaga skonstruowania niezależnego (od silnika) układu smarującego wyposażonego w wagę, mierzącą ilość oleju gromadzącego się w zbiorniku. Metodologię tego typu wartościowania przedstawiono m.in. w publikacji [2], która zawiera wyniki badań firmy Agip

b)

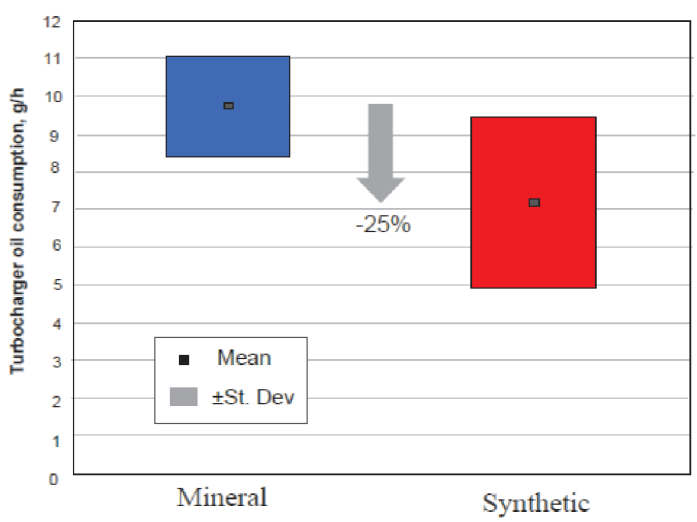

Fig. 3. Turbocharger oil consumption measured with the gravimetric method: a) test stand diagram, b) example results for different oil types Rys. 3. Pomiar zużycia oleju przez turbosprężarkę metodą wagową: a) schemat stanowiska, b) przykładowe wyniki dla różnego typu olejów 


\subsection{Turbocharger rotor vibration tests}

From the scientific development point of view, another important research aspect is the exploration of the rotor displacements during turbocharger operation. Research in this matter can be conducted in two ways. In the first method, optical research of the rotor displacement is used, in the second method its vibrations are recorded.

The examples of the investigations on rotor radial displacements have been presented in [3]. The distance markers in the form of bolt tips (Fig. 4a) enable determining the reference during image recording. The displacements of the rotor tip on the compressor side were recorded. The obtained results of the observations have been presented in Fig. $4 \mathrm{~b}$ and the quantitative information on maximum displacements - Fig. 4c.
Petrol. Schemat stanowiska do pomiaru zużycia oleju przez turbosprężarkę, wraz z wynikami dla oleju mineralnego i syntetycznego, przedstawiono na rys. 3. Z badań wynika, że zużycie oleju przez turbosprężarkę w danych warunkach zmniejsza się o $25 \%$ na korzyść stosowania oleju syntetycznego zamiast mineralnego.

\subsection{Badania nad drganiami wirnika turbosprężarki}

Z punktu widzenia naukowego i rozwojowego, kolejnym ważnym aspektem badawczym jest poznanie przemieszczeń wirnika podczas pracy turbosprężarki. Badania w tym zakresie można prowadzić dwoma sposobami. W pierwszym wykorzystuje się badania optyczne przemieszczeń wirnika, w drugim rejestruje się jego drgania.

Przykłady badań nad przemieszczeniami promieniowymi wirnika przedstawiono w publikacji [3]. Dzięki a)

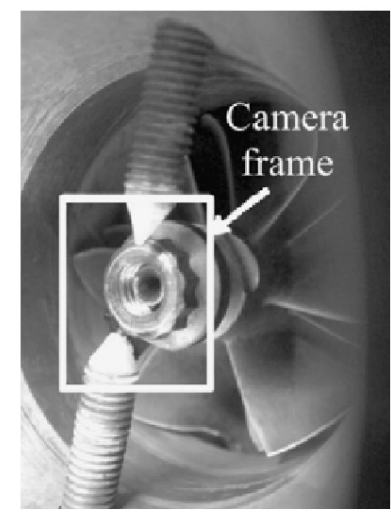

b)

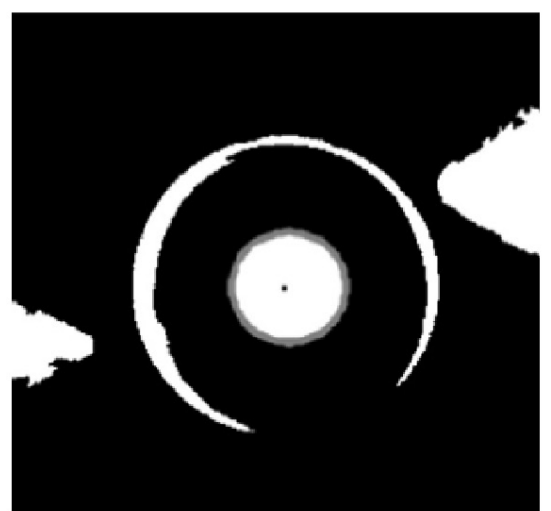

c)

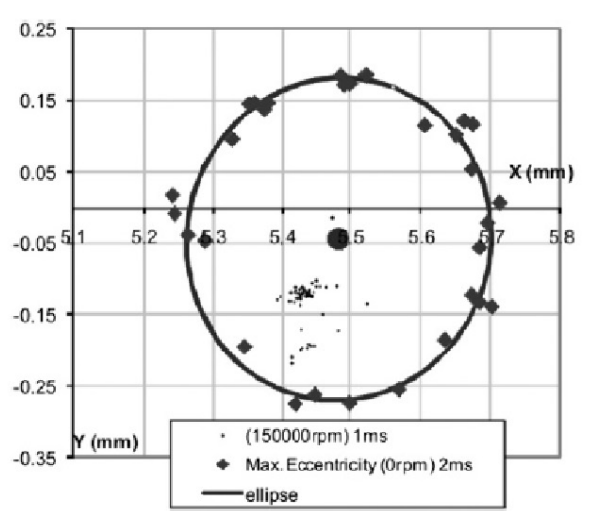

Fig. 4. Registration of the radial displacement of the turbocharger rotor - optical method: a) object of the investigations, b) monochromatic observation, c) quantitative graph of the displacement

Rys. 4. Rejestracja promieniowego przemieszczenia wirnika turbosprężarki metoda optyczną: a) widok obiektu badań, b) monochromatyczny widok obserwacji, c) ilościowy wykres przemieszczeń

Similarly to the optical method, we can use the method of the rotor own vibrations measurement based on a gyroscopic analysis. Discussions on the research conduced with the use of this method are included in [4]. A diagram of the measurement has been shown in Fig. 5. Similarly to the optical method, the measurement was made at the end of the turbocharger shaft on the side of the turbocharger rotor. The difference in the applied method consists in determining of the micro displacements in the $\mathrm{x}$ and $\mathrm{y}$ axes. Analyzing the displacements of the measurement point (Fig. 5), we can determine the source of the vibration signals, answer the questions whether a given displacement is a result of bending of the turbocharger shaft or the phenomena occurring inside the bearings.

\subsection{Cooperation of the turbocharger with additional power receivers}

In a turbocharger a mechanical coupling of the turbine and the compressor with the same shaft allows an almost $100 \%$ efficient transfer of the torque from the turbine to the compressor. The problem seems to be the engine that has a variable charge demand under different conditions and znacznikom odległości w postaci wierzchołków wkrętów (rys. 4a) możliwe jest wyznaczenie układu odniesienia do badań prowadzonych przez filmowanie. Rejestrowano przemieszczenia zakończenia wirnika od strony sprężarki. Otrzymane wyniki obserwacji przedstawiono na rys. 4b, natomiast informację ilościową o maksymalnych przemieszczeniach na rys. $4 \mathrm{c}$.

Analogicznie do metody optycznej można wykorzystać metodę pomiaru drgań własnych wirnika na podstawie analizy żyroskopowej. Dyskusję na temat badań prowadzonych tą metodą zawarto w publikacji [4]. Schemat ideowy pomiaru przedstawiono na rys. 5. Podobnie jak przy stosowaniu metody optycznej, również tutaj dokonywano pomiaru w końcowej części wału turbosprężarki, od strony wirnika sprężarki. Różnica w zastosowanej metodzie polega na określaniu mikroprzemieszczeń w płaszczyźnie x i y. Analizując odpowiednie przemieszczenia punktu pomiarowego (rys. 5), można określać źródło pochodzenia sygnałów drganiowych, odpowiedzieć na pytania, czy dane przemieszczenie wynika z ugięcia wału wirnika, czy np. zjawisk zachodzących w łożyskach. 
a)

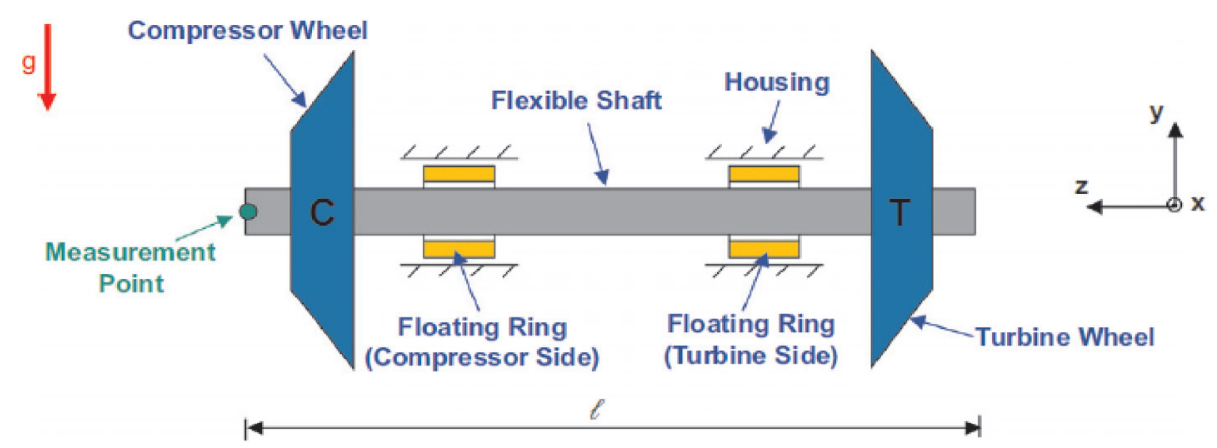

b)

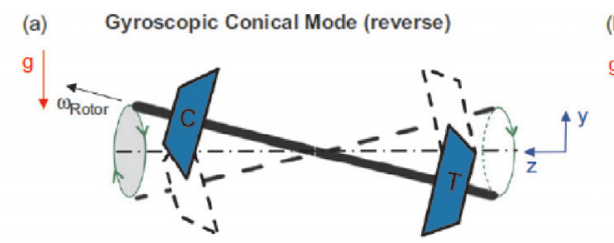

(c) Gyroscopic Translational Mode (reverse)

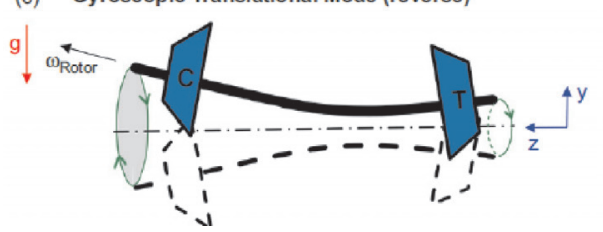

(d)
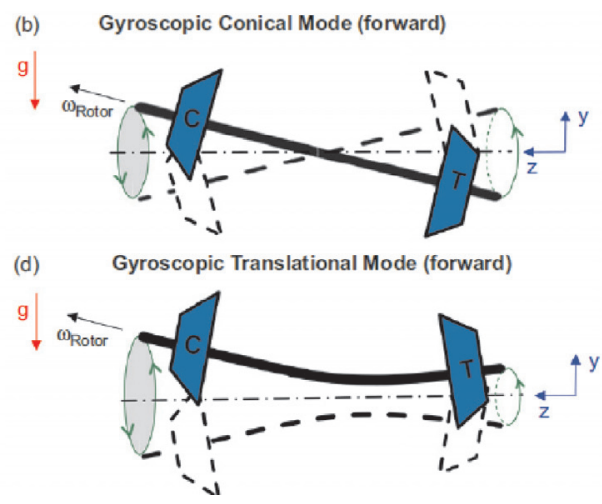

Fig. 5. Measurement of the turbocharger own vibrations with the gyroscopic method: a) diagram, b) interpretation of the obtained results

Rys. 5. Pomiar drgań własnych wirnika turbosprężarki metoda żyroskopowa: a) schemat ideowy, b) interpretacja otrzymanych wyników

states of operation. Partly, flow adjustment is applied (wastegate or VGT - variable geometry turbocharger), yet, the demand for precise adjustment is still growing. There are concepts related to the use of the exhaust gas energy for the generation of electricity. There are two basic possibilities in this respect: giving up the mechanical connection of the turbine with the compressor and an introduction of an additional device cooperating with the turbocharger rotor.

In relation to the first problem, publication [5] presents information related to the actual realization of the assumption of separating the turbine from the compressor. In the
2.4. Współpraca turbosprężarki z dodatkowymi odbiornikami mocy

W turbosprężarce mechaniczne sprzężenie wspólnym wałem sprężarki i turbiny pozwala prawie bezstratnie przenieść moment obrotowy z turbiny na sprężarkę. Problematyczne jest natomiast sprostanie wymaganiu stawianemu przez silnik spalinowy, polegające na zmiennym zapotrzebowaniu na doładowanie w różnych warunkach i stanach pracy. Częściowo stosuje się regulację przepływową (m.in. upustową bądź zmienną geometrię kierownicy), lecz zapotrzebowanie na precyzyjną regulację wzrasta. Istnieją również koncepcje wykorzystania energii spalin do wytwarzania prądu elektrycznego. W odpowiedzi na te zagadnienia badawcze stwierdza się, że istnieją dwie podstawowe możliwości: po pierwsze - rezygnacja z mechanicznej koneksji turbiny i sprężarki, po drugie - wprowadzenie dodatkowego urządzenia współpracującego z wirnikiem turbosprężarki.

$\mathrm{W}$ odniesieniu do pierwszego zagadnienia w publikacji [5] przedstawiono informacje dotyczące fizycznej realizacji założenia oddzielenia turbiny od sprężarki. W opisywanym przypadku turbina za pośrednictwem przekładni redukującej prędkość obrotową napędza synchroniczny generator prądu (rys. 6a). Sprężarka natomiast napędzana zostaje za pomocą a)

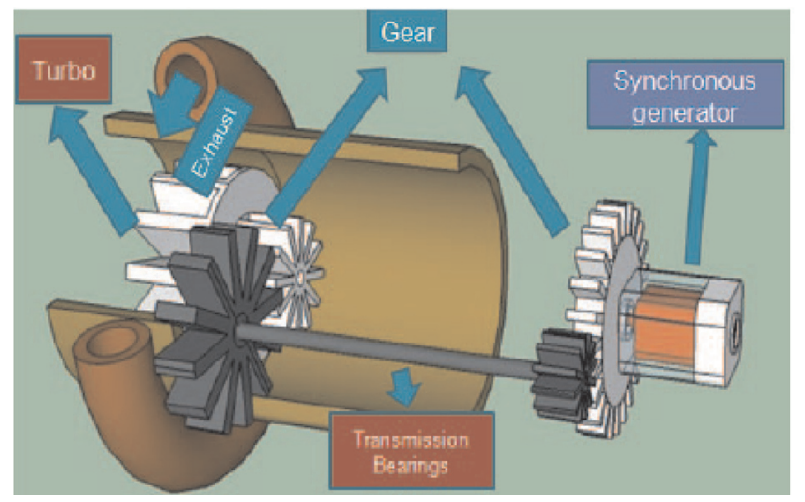

b)

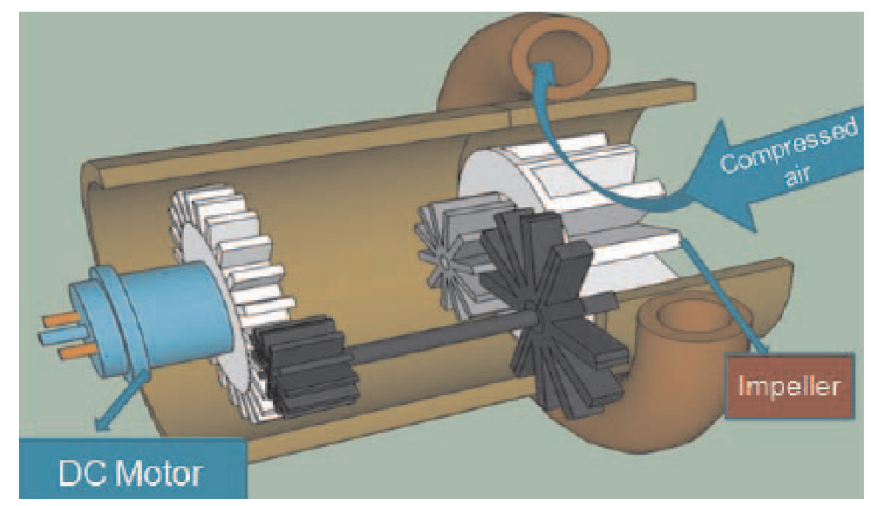

Fig. 6. Schematics of mechanical separation of the turbine and compressor coupling: a) power generation by the turbine, b) electrical drive of the compressor

Rys. 6. Schemat rozdzielenia mechanicznego sprzężenia turbiny i sprężarki: a) generacja prądu przez turbinę, b) napęd elektryczny sprężarki 
described case the turbine, through a mechanical speed reducer drives a synchronous power generator (Fig. 6a). The compressor is driven by a DC electric motor, also through a gearset (Fig. 6b). This solution has the advantage of providing the electricity not only for the use of the compressor but other energy receivers; it can also be accumulated in supercapacitors or a battery.

In reference to the second case the information can be found in [6]. The mechanical separation of the turbine and the compressor is not given up but an additional element is introduced between the turbine and the compressor. This element is an ultra fast brushless electric motor with permanent magnets that can operate as a generator. On one hand, it uses the surplus of power generated by the turbine and on the other hand, it helps the turbocharger reach its operating speed. In the presented solution the motor was capable of generating rated power of approximately $2 \mathrm{~kW}$ (Fig. 7). elektrycznego silnika prądu stałego, także przez przekładnię (rys. 6b). Rozwiązanie takie ma ponadto zaletę wykorzystania wytworzonego prądu nie tylko do napędu sprężarki, ale też innych odbiorników; może być on też magazynowany w superkondensatorach lub akumulatorze.

W odniesieniu do drugiego przypadku informacje można znaleźć w studium [6]. Nie rezygnuje się tu z rozdzielenia mechanicznego turbiny i sprężarki, a wprowadza się dodatkowy element pomiędzy turbinę a sprężarkę. Elementem tym jest ultraszybki, bezszczotkowy silnik elektryczny z magnesami trwałymi, z możliwością pracy jako generator. $\mathrm{Z}$ jednej strony wykorzystuje on nadwyżkę mocy wytwarzaną przez turbinę, z drugiej strony wspomaga szybsze osiągnięcie prędkości obrotowej turbosprężarki. W przedstawionym rozwiązaniu silnik był zdolny do wytworzenia w warunkach znamionowych ok. $2 \mathrm{~kW}$ mocy (rys. 7).
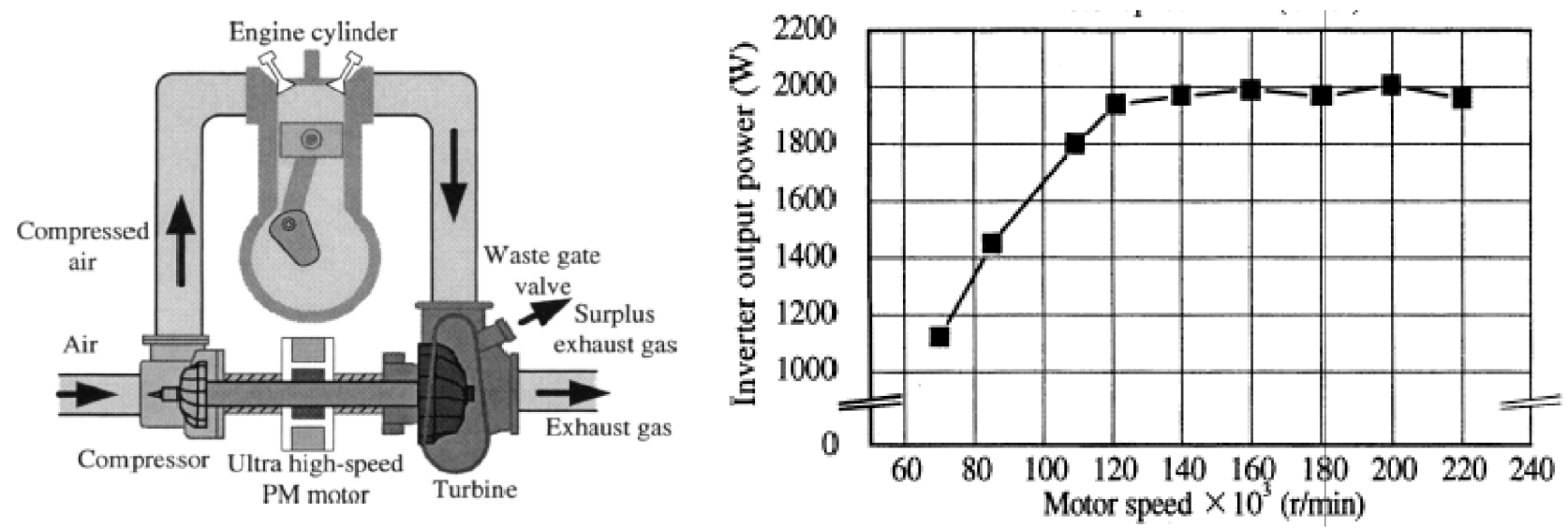

Fig. 7. Fitting of an additional electric motor-generator on the turbocharger shaft: a) diagram, b) characteristics of the generator power output depending on the shaft speed

Rys. 7. Montaż dodatkowego silnikogeneratora elektrycznego na wale turbosprężarki: a) schemat uktadu, b) charakterystyka mocy wyjściowej generatora $w$ zależności od prędkości obrotowej wału

\subsection{Tests in operation}

Due to disadvantageous operating conditions of turbochargers such as high operating temperature of the exhaust gas, very high speeds of up to $250000 \mathrm{rpm}$, precise design and specificity of the fitting they are susceptible to damage or malfunctions.

Turbocharger dysfunctions can be divided in terms of reasons for their occurrence. They are caused, inter alia, by:

- drop in the oil pressure or its instantaneous lack (Fig. $8 \mathrm{a})$,

- intermittent oil feed,

- use of poor quality oil,

- overheating (Fig. 8b),

- foreign bodies that get into the intake manifold (Fig. 9).

A turbocharger is lubricated by the oil taken from the lubrication system of an engine, hence the properties of the oil resulting from its operation in the engine deteriorate. The

\subsection{Badania eksploatacyjne}

Ze względu na niekorzystne warunki pracy turbosprężarek, m.in. wysoką temperaturę spalin, bardzo wysokie prędkości obrotowe dochodzące do 250000 obr/min, precyzyjną konstrukcję oraz utrudnioną zabudowę, podczas eksploatacji narażone są one na uszkodzenia i awarie.

Dysfunkcje turbosprężarek można podzielić ze względu na genezę ich powstawania. Są one spowodowane między innymi przez:

- spadek ciśnienia oleju lub chwilowy jego brak (rys. 8a),

- przerwę w dostawie oleju,

- użycie oleju złej jakości,

- przegrzanie (rys. 8b),

- ciało obce, które przedostało się do kolektora dolotowego (rys. 9).

Turbosprężarka smarowana jest olejem pochodzącym z magistrali olejowej silnika, zatem właściwości oleju na 
a)

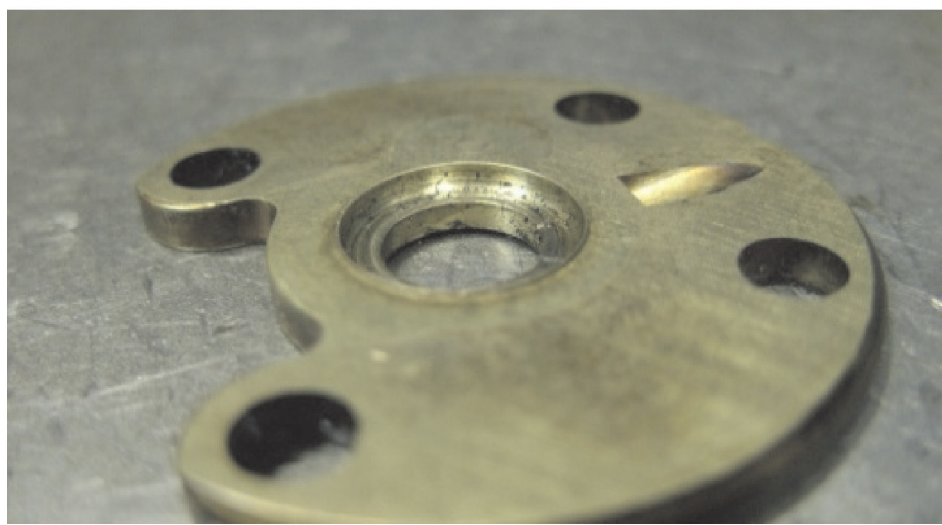

b)

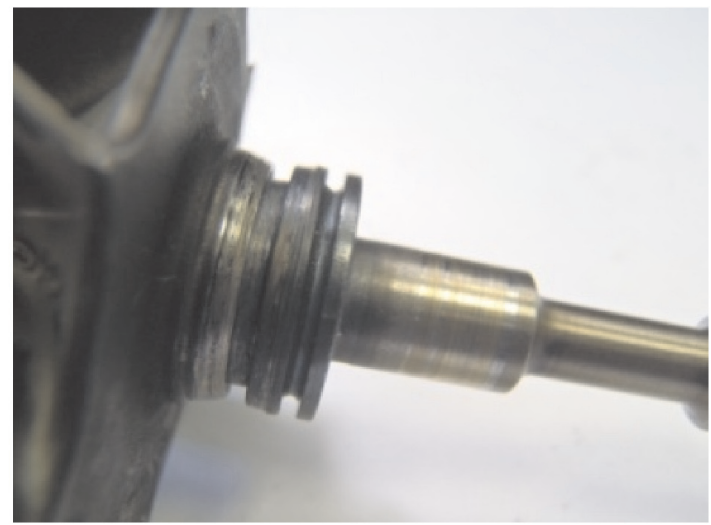

Fig. 8. Turbocharger component damage caused by oil pressure drop: a) permanent deformations, scratches around the bearings, b) overheated rotor shaft

Rys. 8. Uszkodzenia elementów turbosprężarek wywołane spadkiem ciśnienia oleju: a) trwałe zniekształcenia, rysy w obrębie łożysk, b) przegrzany wat wirnika

lubricant in its volume may have macro particle matter (products of friction of the kinematic pairs, corrosion etc.) that cut, scratch or groove the surface of the lubrication nodes.

Overheating of turbocharger elements is caused by two things: excess temperature of the exhaust gas (for diesel engines $>850{ }^{\circ} \mathrm{C}$, and gasoline engines $>1050{ }^{\circ} \mathrm{C}$ ) and a sudden engine stop preceded by driving under heavy engine duty and high engine speed. The hot exhaust gas heats up the turbocharger elements, particularly the cast iron shroud (through conductance) and the turbocharger central body.

The mechanism of the damage caused by a foreign body in the intake or exhaust manifold is erosive, it depends on the size of the body that interacts with the speeding vanes. Even the smallest elements transported along the air or exhaust flow heavily interact with the vanes when getting in contact with the rotor due to high kinetic energy of the gas.

a)

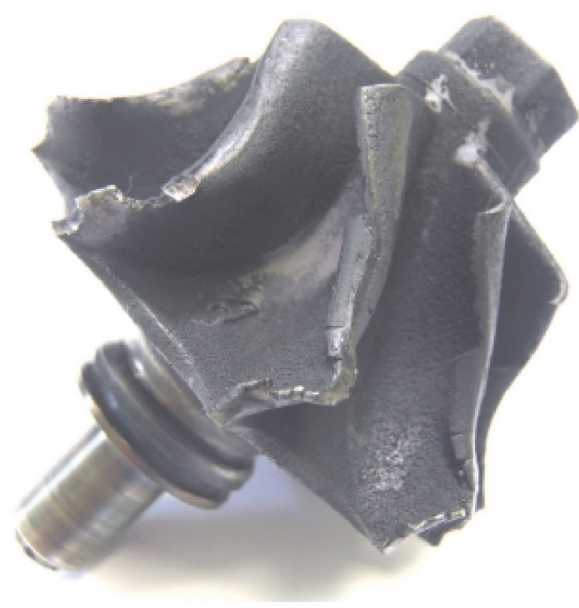

skutek jego pracy w warunkach silnikowych pogarszają się. Lubrykant w swej objętości posiadać może stałe makrocząstki (np. produkty zużycia ściernego elementów silnika, produkty zużycia korozyjnego itp.), które skrawają, rysują, bruzdują warstwy wierzchnie węzłów smarnych.

Przegrzanie elementów turbosprężarki ma zasadniczo dwa źródła: zbyt wysoka temperatura spalin (dla silników $\mathrm{ZS}>850{ }^{\circ} \mathrm{C}$, dla $\mathrm{ZI}>1050{ }^{\circ} \mathrm{C}$ ) oraz nagłe unieruchomienie silnika poprzedzone jazdą ze znacznym obciążeniem i wysoką prędkością obrotową. Gorące spaliny silnie nagrzewają (zwłaszcza na drodze przewodzenia) elementy turbosprężarki - w szczególności żeliwny korpus turbiny, a także korpus środkowy.

Mechanizm uszkodzeń spowodowanych przez przedostanie się ciała obcego do układu dolotowego lub wylotowego jest erozyjny, zależy od wielkości tego ciała, które wchodzi $\mathrm{w}$ reakcję z rozpędzonymi łopatkami wirnika. Nawet naj-

b)

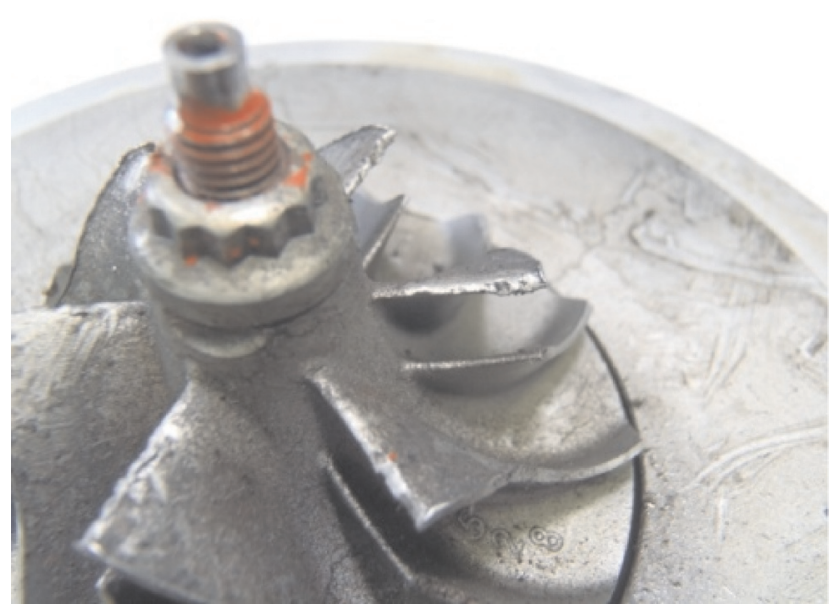

Fig. 9. Damage to the turbocharger elements caused by a foreign body entered through the intake manifold: a) torn shaft with damaged turbine vanes, b) compressor rotor with damaged vanes

Rys. 9. Uszkodzenia elementów turbosprężarek wywołane przedostaniem się ciała obcego do kolektora dolotowego: a) zerwany wat z uszkodzonymi topatami wirnika turbiny, b) wirnik sprężarki z uszkodzonymi topatkami 
There is an economically justifiable need to test turbochargers, as they are prone to various failures during operation. A quick reaction to malfunctions of the main turbocharger elements reduces the costs because, in the first stage of the malfunction, it only involves the shaft bearing system. There is no quantitative information on the process of damage of the turbocharger components. There is a gap in the description of the phenomena accompanying the damage processes of turbochargers. There are no sensors providing the driver with information on the technical condition of the most significant components of the engine turbocharger. There are no systems diagnosing the in-operation charging parameters either. It is commonly known that the damage has a snowball effect, is erosive and total destruction occurs suddenly.

\section{Description of the turbocharger test stand}

For the drive of the turbocharger, a flow of hot gas is used generated by the exhaust generator (combustion engine). The schematic of operation of the system has been presented in Fig. 10b. The air with the fuel is fed to the engine combustion chamber ' $\mathrm{CE}$ ', where the mixture is combusted. Upon combustion the exhaust, gas is directed onto the rotor vanes propelling the turbocharger system. The compressed air is not used in any way and the system is not connected to any engine intake. The exhaust system is connected to the laboratory exhaust ducts.

a)

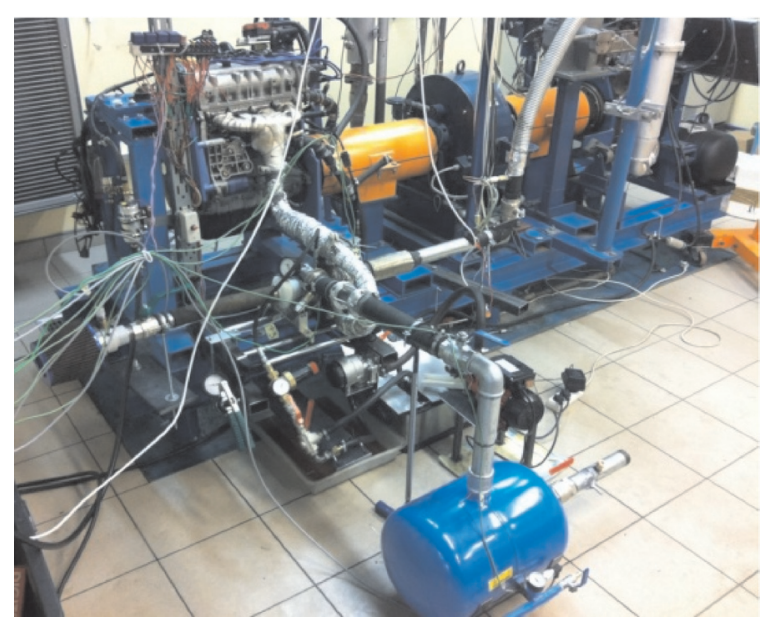

mniejszy element niesiony wraz ze strumieniem spalin lub powietrza, trafiając na koło wirnikowe, w wyniku znacznej energii strumienia gazu, silnie oddziałuje z łopatkami.

Istnieje ekonomicznie uzasadniona potrzeba badań turbosprężarek, które podczas eksploatacji ulegają awariom różnego typu. Szybka reakcja na dysfunkcje głównego elementu układu doładowania silnika skutkuje minimalnym nakładem kosztów, ponieważ w pierwszej fazie awarii uszkodzeniu ulega najczęściej układ łożyskowania wału turbosprężarki. Nie ma informacji ilościowych o procesie niszczenia tych podzespołów. Istnieje luka w opisie zjawisk towarzyszących uszkadzaniu się turbosprężarek. Brak jest czujników, które mogłyby dostarczyć kierowcy informacji o stanie technicznym najistotniejszego elementu w układzie doładowania silnika. Brak jest również systemów diagnozujących parametry doładowania podczas pracy silnika. Powszechnie wiadomo, iż zniszczenia mają charakter erozyjny, lawinowy, a całkowita destrukcja następuje gwałtownie.

\section{Opis stanowiska do badań turbosprężarek}

Do napędu turbosprężarki wykorzystuje się strumień gorących gazów pochodzących z komory spalania silnika spalinowego, będący wytwornicą spalin. Schemat działania układu przedstawiono na rys. 10b. Powietrze wraz z paliwem dostarczane jest do komory spalania silnika spalinowego „SSp”, gdzie następuje spalanie mieszanki. Po spaleniu gazy trafiające na łopatki wirnika turbiny wprowadzają

b)

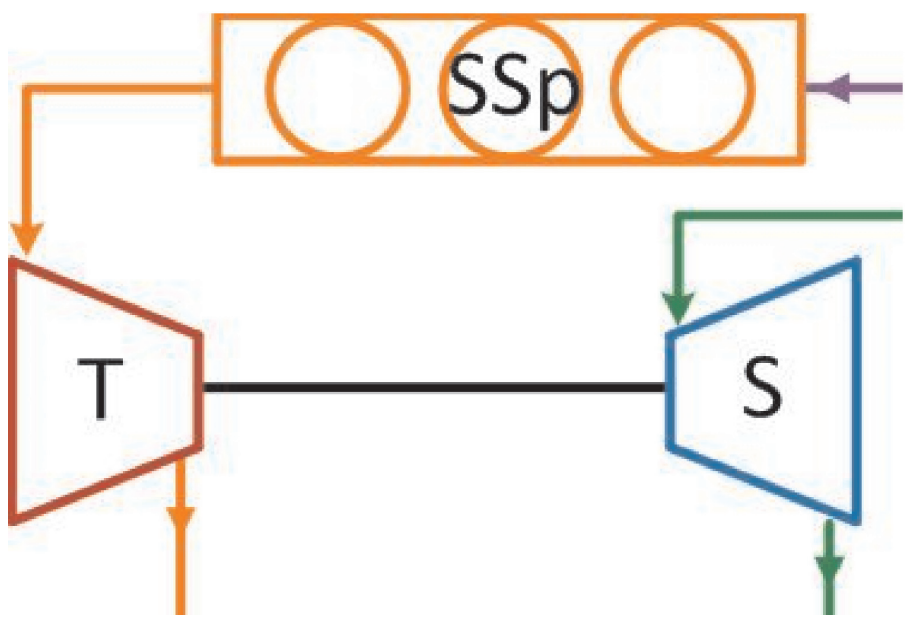

Fig. 10. Test stand; a) overview, b) diagram

Rys. 10. Stanowisko badawcze; a) widok, b) schemat ideowy

The exhaust gas generator used for the drive of the turbocharger uses a Fiat $1.2 \mathrm{dm}^{3}$ engine (MPFI) of the following technical specifications:

- power output: $52 \mathrm{~kW} / 6000 \mathrm{~min}^{-1}$,

- torque: $102 \mathrm{~N} \cdot \mathrm{m}$,

- number of cylinders: 4.

The research engine was installed on a test bed fitted with an Eddy-current brake (AMX 210/100 $\mathrm{P}_{\text {max }}=100 \mathrm{~kW}, \mathrm{M}_{\mathrm{o}-\max }$ $\left.=240 \mathrm{~N} \cdot \mathrm{m}, \mathrm{n}_{\max }=10000 \mathrm{rpm}\right)$. The test stand was equipped with a gravimetric fuel meter (AMX 212), intercooler and w ruch układ turbosprężarki. Sprężone powietrze nie jest w żaden sposób dalej wykorzystywane, układ nie jest połączony z układem dolotowym silnika. Układ wylotowy silnika spalinowego połączony jest $\mathrm{z}$ instalacją wylotową laboratorium.

Wytwornica spalin zastosowana do napędu turbosprężarki wykorzystuje silnik produkcji Fiata 1,2 $\mathrm{dm}^{3}$ o oznaczeniu handlowym MPFI. Charakteryzuje się on następującymi parametrami konstrukcyjnymi:

- moc: $52 \mathrm{~kW} / 6000 \mathrm{~min}^{-1}$, 
a computer for the dynamic recording of the measurement results.

For the measurements and data acquisition the following were used:

- analog-digital card by iOTech Personal Daq/3000 - 2 x 4 digital channels,

- turbocharger speed sensor - Turbo Speed Sensor by AVL, whose principle of operation is measuring the frequency of the light reflected from the marker placed on the compressor rotor.

\section{Methodology and reserch}

The performed works aimed at exploring the research possibilities of the test stand. The aim of the investigations was to accelerate the Garrett $1544 \mathrm{~V}$ turbocharger to possibly high speeds in order to test the parameters of the generated exhaust gas.

The tests were conducted on a specially prepared test stand. For the analysis of the test stand designed for turbocharger acceleration the following physical quantities were measured:

- speed of the exhaust generator - using an engine speed control system by Automex,

- duty of the exhaust generator - using a brake control system by Automex,

- speed of the turbocharger - through a speed optical sensor (TurboSpeed sensor by AVL),

- temperature in the intake and exhaust channels of the compressor - through k-type thermocouples,

- temperature in the intake and exhaust channels of the turbine - through k-type thermocouples,

- pressures in the intake and exhaust channels of the turbine and the compressor - through a G450 differential pressure sensor.

The parameters of the speeds, pressures and temperature were recorded with the frequency of $1 \mathrm{~Hz}$. The measurements were conducted under the conditions of constant speeds and loads for selected engine work points. The temperature of the engine fluids was as follows:

- coolant $90^{\circ} \mathrm{C}$,

- engine oil $85^{\circ} \mathrm{C}$.

During the tests, these values remained unchanged. The ambient temperature was $5{ }^{\circ} \mathrm{C}$ and the ambient pressure $1025 \mathrm{hPa}$.

\section{Results and discussion}

The performed experiment enabled an acceleration of the turbocharger shaft to the maximum speed of $100 \mathrm{rpm}$. This speed range was approximately $50 \%$ of the maximum values of a typical rate in a turbocharger fitted in a vehicle. It might be of significance that the enthalpy of the exhaust gas generated by the applied generator (at the engine speed of $4000 \mathrm{rpm}$ and load of $60 \mathrm{~N} \cdot \mathrm{m}$ ) is insufficient to reach the maximum speeds of the Garrett $1544 \mathrm{~V}$ turbocharger. The obtained range of speeds, however, was sufficient to conduct research and analysis (Fig. 11).

The commonplace phenomenon that the exhaust gas enthalpy grows proportionally to the gas flow rate is tightly
- moment obrotowy: $102 \mathrm{~N} \cdot \mathrm{m}$,

- liczba cylindrów: 4.

Silnik badawczy zamontowany jest na hamownianym stanowisku badawczym wyposażonym w elektrowirowy hamulec typu AMX 210/100 $\left(\mathrm{P}_{\max }=100 \mathrm{~kW}, \mathrm{M}_{\text {o-max }}=240\right.$ $\left.\mathrm{N} \cdot \mathrm{m}, \mathrm{n}_{\max }=10000 \mathrm{obr} / \mathrm{min}\right)$. Stanowisko wyposażono w wagową miernicę paliwa AMX 212, układ chłodzenia powietrza doładowanego oraz komputer do rejestracji wyników pomiarów w sposób dynamiczny.

Do prowadzenia pomiarów oraz akwizycji danych wykorzystano:

- kartę analogowo-cyfrową firmy iOTech Personal Daq/3000 - 2 x 4 kanały cyfrowe,

- czujnik do pomiaru prędkości obrotowej wału turbosprężarki Turbo Speed Sensor firmy AVL, którego działanie polega na pomiarze częstotliwości światła odbitego od znacznika umieszczonego na wirniku sprężarki.

\section{Metodyka i przebieg badań}

Wykonane prace miały na celu sprawdzenie możliwości badawczych stanowiska pomiarowego. Istotą badań było wprowadzenie wału turbosprężarki Garrett $1544 \mathrm{~V}$ w ruch obrotowy do możliwie wysokich prędkości obrotowych w celu zbadania parametrów gazów wylotowych wytwornicy spalin.

Badania prowadzono na specjalnie przygotowanym stanowisku badawczym zbudowanym w hamowni silnikowej. Do analizy wybranych możliwości badawczych stanowiska do rozpędzania turbosprężarek wykonano pomiary następujących wielkości fizycznych:

- prędkości obrotowych wytwornicy spalin - przy wykorzystaniu układu sterowania prędkością obrotową wału korbowego silnika firmy Automex,

- obciążenia wytwornicy spalin - przy wykorzystaniu układu sterowania hamulcem elektrowirowym firmy Automex,

- prędkości obrotowych wału turbosprężarki - za pomocą optycznego czujnika prędkości TurboSpeed sensor firmy AVL,

- temperatury w kanałach dolotowych i wylotowych sprężarki - za pomocą termopar typu K,

- temperatury w kanałach dolotowych i wylotowych turbiny - termopary typu K,

- ciśnień w kanałach dolotowych i wylotowych turbiny oraz sprężarki - za pośrednictwem czujnika różnicowego G450.

Parametry prędkości, ciśnień oraz temperatur rejestrowano $\mathrm{z}$ częstotliwością $1 \mathrm{~Hz}$. Pomiary prowadzono w warunkach stałych prędkości obrotowych oraz obciążeń dla wybranych punktów pracy. Temperatura płynów eksploatacyjnych:

- ciecz chłodząca $90{ }^{\circ} \mathrm{C}$,

- olej $85^{\circ} \mathrm{C}$.

Podczas badań wartości te nie zmieniały się. Temperatura otoczenia wynosiła $5{ }^{\circ} \mathrm{C}$, a ciśnienie $1025 \mathrm{hPa}$.

\section{Dyskusja wyników}

Przeprowadzony eksperyment umożliwił rozpędzenie wału turbosprężarki do maksymalnej prędkości rzędu 100 


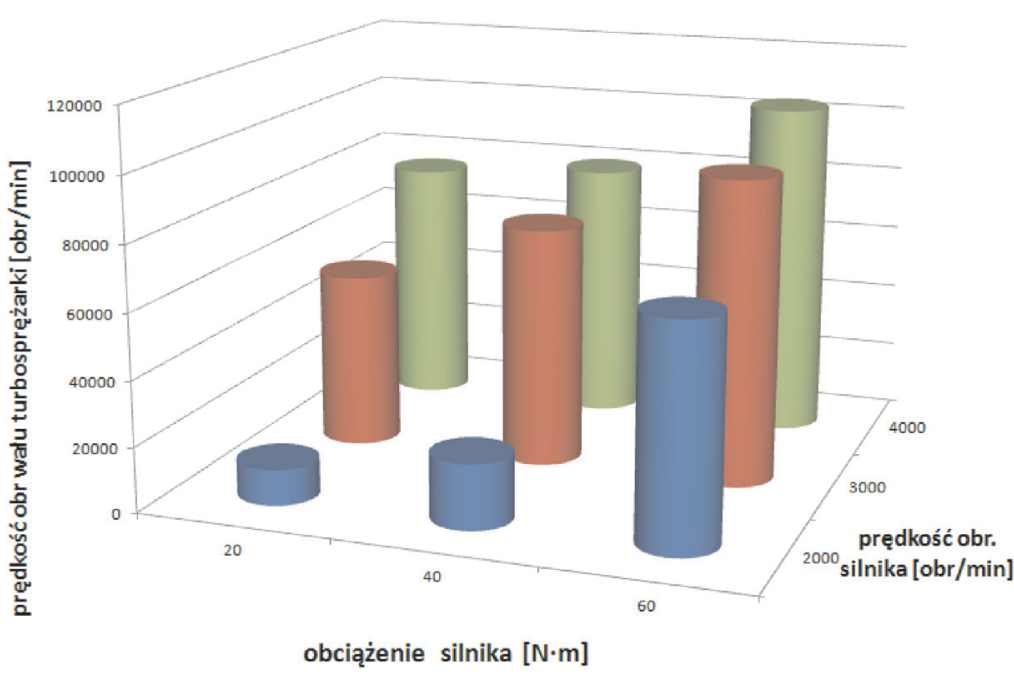

Fig. 11. The turbocharger speed as a function of engine speed and load Rys. 11. Zależność prędkości obrotowej watu turbosprężarki w funkcji prędkości obrotowej i obciążenia silnika

correlated with the engine speed and its loads are well reflected by the results shown in Fig. 11. An increase in the engine speed or the duty of the exhaust generator leads to an increase in the speed of the turbocharger shaft. It is noteworthy that the same range of turbocharger shaft speeds can be obtained by a proper control of the engine speed and loads i.e. applying $20 \mathrm{~N} \cdot \mathrm{m}$ of torque at $4000 \mathrm{rpm}, 40 \mathrm{~N} \cdot \mathrm{m}$ of torque at $3000 \mathrm{rpm}$ and $60 \mathrm{~N} \cdot \mathrm{m}$ at $2000 \mathrm{rpm}$. In all three cases, the same turbocharger speed was obtained of around $80.000 \mathrm{rpm}$.

In the turbocharger research the key factor may be the obtainment of the same turbocharger shaft speed by changing the engine speed and load parameters, which will be characterized by an even charging rate at different mechanical and thermal tensions. This dependence has been presented in Fig. 12.

The temperature difference of the exhaust gas upstream and downstream of the turbocharger at variable engine load from 20 to $60 \mathrm{~N} \cdot \mathrm{m}$ oscillates around $120-180{ }^{\circ} \mathrm{C}$. The presented measurements were carried out at constant speeds of around $2000 \mathrm{rpm}$.

\section{Conclusions}

From the presented analysis, it results that the scope of turbocharger research is very wide. The assessment of the cooperation of turbochargers or turbines alone with power receivers (generators) becomes a frequent process. Due to the popularity of the turbocharger application, much attention is devoted to the cooperation of this component with the engine tys. obr/min. Ten zakres prędkości obrotowych to ok. $50 \%$ wartości maksymalnych nominalnie pracującej turbosprężarki tego typu zamontowanej w pojeździe. Istotne może być to, iż entalpia gazów wylotowych generowana przez zastosowaną wytwornicę (przy prędkości wału korbowego 4000 obr/min i obciążeniu równym $60 \mathrm{~N} \cdot \mathrm{m}$ ) jest niewystarczająca, aby osiągnąć maksymalne prędkości wału turbosprężarki typu Garrett 1544 V. Niemniej jednak, uzyskany podczas badań zakres 100 tys. obr/min jest wystarczający do prowadzenia prac i analiz (rys. 11).

Powszechnie znane zjawisko, iż entalpia spalin wzrasta proporcjonalnie do prędkości przepływu strumienia gazu, który jest ściśle skorelowany z prędkością obrotową silnika spalinowego, i jego obciążenia doskonale odzwierciedlają wyniki przedstawione graficznie na rys. 11. Zwiększanie prędkości obrotowej wału korbowego lub obciążenia wytwornicy spalin powoduje wzrost prędkości obrotowej wału turbosprężarki. Godnym uwagi staje się fakt, iż ten sam zakres prędkości obrotowych wału turbosprężarki uzyskać można, regulując odpowiednio obciążenie oraz prędkość obrotową wału korbowego silnika, tj. np. zadając obciążenie $20 \mathrm{~N} \cdot \mathrm{m}$ przy $4000 \mathrm{obr} / \mathrm{min}, 40 \mathrm{~N} \cdot \mathrm{m}$ przy $3000 \mathrm{obr} / \mathrm{min}$ oraz $60 \mathrm{~N} \cdot \mathrm{m}$ przy $2000 \mathrm{obr} / \mathrm{min}$. W trzech przypadkach uzyskano równą prędkość obrotową rzędu 80 tys. obr/min.

Podczas badań turbosprężarek kluczowe może okazać się zjawisko uzyskiwania, przez zmiany parametrów prędkości oraz obciążenia silnika, tej samej prędkości obrotowej wału turbosprężarki, co charakteryzować się będzie równym stopniem doładowania przy innych wartościach naprężeń cieplnych oraz mechanicznych układu doładowania. Zależność tę przedstawiono na rys. 12.

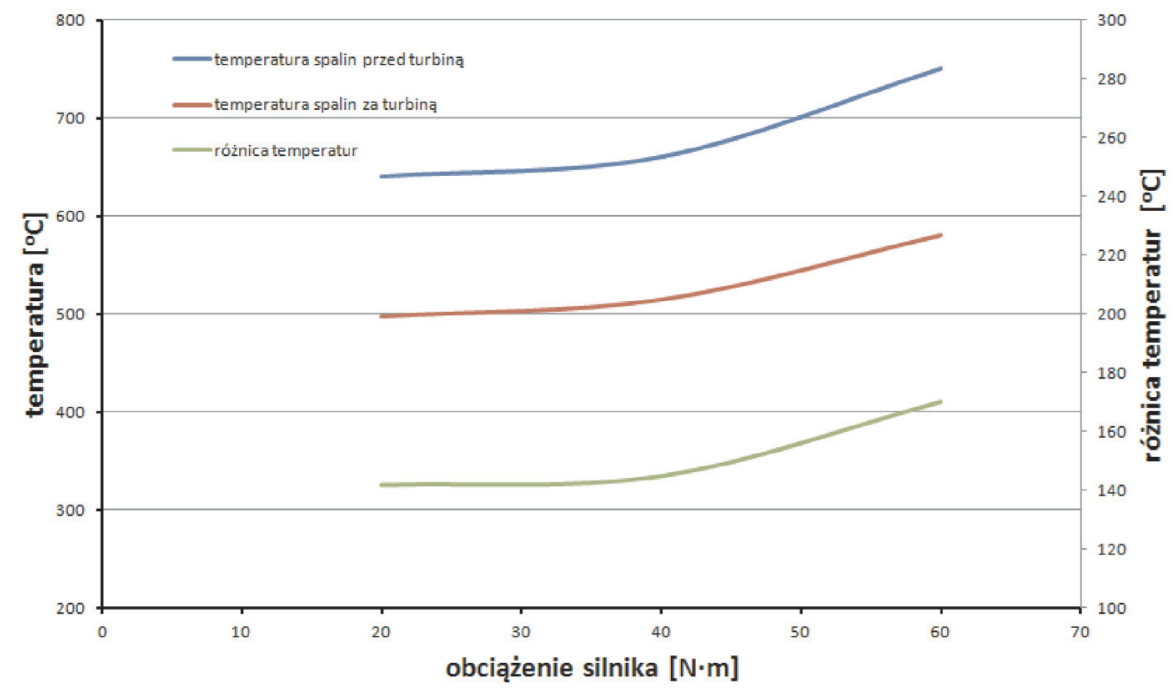

Fig. 12. The influence of the engine load on the temperature difference upstream and downstream of the turbocharger

Rys. 12. Wpływ obciążenia silnika na różnicę temperatur przed i za turbosprężarka 
in in-operation investigations, including the destructive processes. The discussed research can be realized on appropriate test stands. For the in-operation tests, engine is the best exhaust generator. It is important that the applied engine is not fitted with a turbocharger and the test stand has a standalone turbocharger lubrication system.

The obtained results serve a purpose of identification and validation of the test stand operation and will be a reference for similar research.

The applied research method has been validated and may be used in further turbocharger research.

\section{Bibliography/Literatura}

[1] Delvigne T.: Oil Consumption Sources in a Modern Gasoline Engine Including Contribution of Blow-by Separator and Turbocharger: An Experimental Study Based on the Use of Radiotracers. SAE Technical Paper, 2010-01-2256.

[2] Manni M., Carriero M., Roselli A.: A Study of Oil Consumption on a Diesel Engine with Independently Lubricated Turbocharger. SAE Technical Paper, 2002-01-2730.

[3] Pastor J., Serrano J., Dolz V, Lopez M, Bouffaud F.: Study of turbocharger shaft motionby means of non-invasiveoptical teniques: Application to the behavior analysis in turbocharger lubrication failures. Mechanical Systems and Signal Processing 32 (2012), p. 292-305.

[4] Schweizera B., Sievertb M.: Nonlinear oscillations of automotive turbocharger turbines. Journal of Soundand Vibration 321 (2009), p. 955-975.

[5] Xiaobin Y., Zheng Z.: With the electrical properties of a new turbocharger. IEEE Technical Paper, 2010, p. 3465-3468.

[6] Noguchi T., Takata Y., Yamashita Y.:220,000-r/min, 2-kW PM Motor Drive for Turbocharger, Electrical Engineering in Japan, Vol. 161, No. 3, 2007.

[7] Turbocharger Test Stand with a Hot Gas Generator for HighPerformance Supercharging Systems. MTZ 10I 2008, Vol. 69.

[8] Filho F., Valle R., Barros J., Hanriot S.: Automotive Turbocharger Maps Building using a Flux Test Stand. SAE Technical Paper, 2002-01-3542.

[9] Griffith R., Mavrosakis P.,: Ball Bearings to the Series Turbochargers for the Caterpillar Heavy-Duty On-Highway Truck Engines, SAE Technical Paper, 2007-01-4235.

Maciej Bieliński, MEng. - Postgraduate in the Faculty of Machines and Transport at Poznan University of Technology.

Mgr inż. Maciej Bielinski - doktorant na Wydziale Maszyn Roboczych i Transportu Politechniki Poznańskiej.

email:maciej.bielinski@doctorate.put.poznan.pl

Paweł Daszkiewicz, MEng. - senior assistant in the Rail Vehicles Institute "TABOR” in Poznan.

Mgr inż. Pawet Daszkiewicz - starszy asystent w Instytucie Pojazdów Szynowych "TABOR" w Poznaniu.

email: pawel.daszkiewicz@wp.pl
Różnica temperatur gazów spalinowych przed i za turbiną przy zmianie obciążenia silnika od 20 do $60 \mathrm{~N} \cdot \mathrm{m}$ waha się w granicach $120-180{ }^{\circ} \mathrm{C}$. Przedstawione pomiary wykonano w warunkach stałych prędkości obrotowych silnika w zakresie $2000 \mathrm{obr} / \mathrm{min}$.

\section{Podsumowanie}

Z przedstawionej analizy wynika, iż nad zagadnieniami związanymi z turbosprężarkami prowadzi się badania w szerokim zakresie. Coraz powszechniej prowadzi się wartościowanie współpracy turbosprężarki lub samej turbiny z odbiornikami mocy (generator). Ze względu na powszechność stosowania turbosprężarki wiele uwagi poświęca się współpracy tego elementu z silnikiem spalinowym w badaniach eksploatacyjnych, uwzględniając procesy niszczące. Omówione zakresy badawcze można przeprowadzić dzięki odpowiednim stanowiskom. Do badań eksploatacyjnych najlepiej wykorzystać silnik spalinowy jako wytwornicę spalin. Ważne jest jednak, żeby zastosowany silnik do budowy stanowiska nie posiadał turbodoładowania, a stanowisko wyposażone było w niezależny układ smarowania badanej turbosprężarki.

Uzyskane wyniki pełnią funkcję identyfikacji oraz sprawdzenie poprawności działania stanowiska badawczego i będą stanowiły tło porównawcze dla podobnych badań.

Wykorzystana metoda badawcza została pozytywnie zweryfikowana i może być wykorzystana w dalszych badaniach turbosprężarek.

Prof. Marek Idzior, DSc, DEng. - professor in the Faculty of Machines and Transport at Poznan University of Technology.

Prof. dr hab. inż. Marek Idzior - profesor na Wydziale Maszyn Roboczych i Transportu Politechniki Poznańskiej.

email:marek.idzior@put.poznan.pl

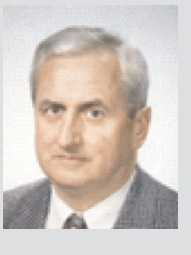

Wojciech Karpiuk, DEng. - doctor in the Faculty of Machines and Transport at Poznan University of Technology.

Drinz. Wojciech Karpiuk-asystent na Wydziale Maszyn Roboczych i Transportu Politechniki Poznańskiej. email: wojciech.karpiuk@put.poznan.pl

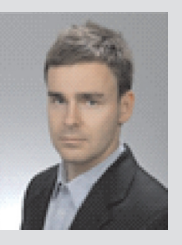

Tomasz Borowczyk, MEng. - Postgraduate in the Faculty of Machines and Transport at Poznan University of Technology.

Mgr inż. Tomasz Borowczyk - doktorant na Wydziale Maszyn Roboczych i Transportu Politechniki Poznańskiej.

email: tomasz.borowczyk@doctorate.put.poznan.pl

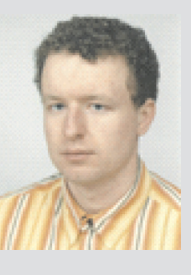

Paweł Stobnicki, DEng. - doctor in the Industrial Institut of Agricultural Engineering in Poznan.

Dr inż. Pawel Stobnicki-asystent w Przemyslowym Instytutcie Maszyn Rolniczych w Poznaniu. email:pawel.stobnicki@pimr.poznan.pl

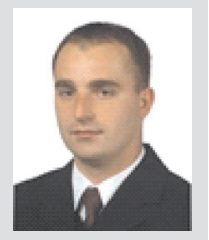

